\title{
SUSTAINABLE PROJECT MANAGEMENT: CASE OF CULTURE PROJECTS IN ZEMGALE PLANNING REGION
}

Sandra Kauranena ${ }^{1}$, Mg.proj.mgmt.; Dina Bite ${ }^{2}$, Dr.sc.soc. and Zenija Kruzmetra ${ }^{3}$, Dr.geogr. $1,2,3$ Latvia University of Life Sciences and Technologies

\begin{abstract}
Adherence to the principles of sustainability in the acquisition of different funds and financial instruments is one of the basic conditions for obtaining funding. In the field of cultural project management, sustainability is more difficult to assess because the concept of culture is multifaceted and not always quantifiable. Identifying and promoting the sustainability of the results of cultural projects outside large cities and in rural areas is particularly important, as each project implemented should serve the growth and cultural development of the area. Unfortunately, the lack of research on this issue proves the need to invest a great deal in identifying and analysing the situation. There is a lack of studies analysing the contribution of cultural projects to the development of regional territories and their long-term benefits. To do this, the research set a goal: to study the practice of ensuring sustainability of results of cultural projects in Zemgale planning region, Latvia. The research used quantitative and qualitative research methods - content analysis of Zemgale Planning Region municipal websites, document research and analysis of Zemgale Planning Region (state institution), as well as semistructured interviews. The study reveals certain practices that municipal authorities are pursuing to ensure the sustainability of cultural projects, such as linking different activities, using the 'project basket' principle etc., but overall it has to be concluded that sustainable cultural project management still needs to be expanded and improved. There is often a lack of links and feedback between project applicants and final beneficiaries. There are no clear indicators to measure sustainability. New approaches need to be found not only to learn how to integrate sustainability principles into project management, but also to introduce a set of convenient and practical steps to make the desirable sustainability scenario described in theory a common practice in cultural project management.
\end{abstract}

Key words: culture projects, sustainability, sustainability assessment, regional development. JEL code: $\mathrm{H} 43, \mathrm{O} 22, \mathrm{Z} 10$

\section{Introduction}

The role of culture in the context of sustainability has been discussed since the concept of sustainable development first began. Various key organizations such as the World Summit on Sustainable Development and UNESCO have also expressed the belief that culture should be included in the concept of sustainable development. UNESCO has publicly expressed this conviction in its "Universal Declaration on Cultural Diversity" (2001) and in the Convention on the Diversity of Cultural Expressions (2005), stating that "creativity, knowledge, diversity and beauty are inevitable space for dialogue on peace and progress, since they are directly related to human development and freedom". Culturally sustainable behavior encourages the public to recognize and identify themselves. Thus, a society that loves the human and social as well as the natural and created environment in which it lives is more prepared, informed, free, caring and willing to engage in other sustainable development issues such as social inclusion, economic growth and environmental balance (Environmental, Cultural...; A New European..., 2018, Council conclusions..., 2014; Asare et.al., 2013). Denise Scammon (Scammon, 2012) justifies adding culture to the concept of sustainability by the importance of a sense of cultural identity and belonging, making sustainability inclusive and contributing to environmental, economic and social goals.

Although different authors have similar views and justifications on the role of culture in sustainable development, the links between culture and sustainability are interpreted differently. First, culture is

\footnotetext{
${ }^{1}$ Sandra Kauranena e-mail:Sandra.Kauranena@gmail.com

2 Dina Bite e-mail: Dina.Bite@llu.Iv

3 Zenija Kruzmetra e-mail: Zenija.Kruzmetra@llu.Iv
} 
given an independent role in sustainability, becoming the fourth element of sustainability. The concept is linked to safeguarding, preserving and preserving cultural capital in its various forms, such as art forms, historical heritage, knowledge and cultural diversity, for future generations. The second way is to interpret culture as a mediator for environmental, social and economic sustainability. In this case, both tangible and intangible culture is seen as an important resource for local and regional economic development, and cultural values and perceptions must be taken into account when assessing ecological and social sustainability. Third, culture is seen as a necessary basis for achieving overall sustainability goals. Culture is viewed as an overarching dimension of sustainability, incorporating elements of sustainability - environment, economy and society. In other words, sustainability becomes integrated into culture, not the other way around, and leads to eco-cultural civilization (Soini and Dessein, 2016).

One of the latest modernizations of the concept of sustainable development came into existence in Slovenia in 2016. The stimulus to the classic model was born because in recent years the EU has witnessed an unprecedented influx of political and economic migrants leaving their homeland to secure a better future in more developed countries. The importance of this process is such that it has already begun to influence the cultural, social and political structures of some EU Member States, and therefore geostrategic security and cultural sustainability, in addition to economic, social and environmental sustainability, should become topical issues for researchers, entrepreneurs and policy makers. Based on these factors, the authors of the study, M.Bervar and A.Bertoncelj propose to develop the concept of sustainable development from five basic elements - economy (material welfare through sustainable growth), justice (social welfare including social cohesion), ecology (environmental prosperity), culture (cultural prosperity through intercultural dialogue) and security (peace and sustainable stability) (Bervar, Bertoncelj, 2016).

The concept of sustainability development often associates with offered models that are similar in content and in substance, differing only in complementary and refinement elements, but there are also different versions in the literature that alter the previously identified approach to sustainability. One example is the three-pillar model of sustainable development developed in 2018 by Clune and Zender. It is a multidisciplinary, solution-based approach, based on three elements: technology and innovation, law and governance, economics and financial incentives. Unlike the classical approach of sustainability, the authors of this model emphasize the transition from the conceptual framework to the implementation and operational structure. While the classical approach defines the potential for sustainability, this approach shows ways to achieve sustainability (Clune, Zender, 2018).

At the same time, specific criteria are needed to answer the questions above about how to ensure this and evaluate results in the field of project management, which combine historical, social and societal challenges, while forming the understanding and values of today's society. English scholars G.B. Guy and J.C. Kibert, in their study on culture as a promoter of development, concluded that growth criteria should be understandable, easy to apply, accessible, and open-ended, meaning unlimited over a given period of time. They should be based on regular (annual) data collection, reflecting an analysis of the current situation and outlining a certain direction (Guy, Kibert, 1998).

Identifying and promoting the sustainability of the results of cultural projects outside large cities and in rural areas is particularly important, as each project implemented should serve the growth and cultural development of the area. Unfortunately, the lack of research on this issue proves the need to invest a great deal in identifying and analysing the situation. There is a lack of studies 
analysing the contribution of cultural projects to the development of regional territories and their long-term benefits (Silvius et.al, 2017; Silvius, Schipper, 2014; Tufinio et.al., 2013).

Based on literature analysis and research, it is important to set criteria that allow understanding and analysing the implementation of the desired development scenario in practice, taking into account the need for quantitative indicators. Figure 1 presents a scheme for assessing the sustainability of cultural project results.

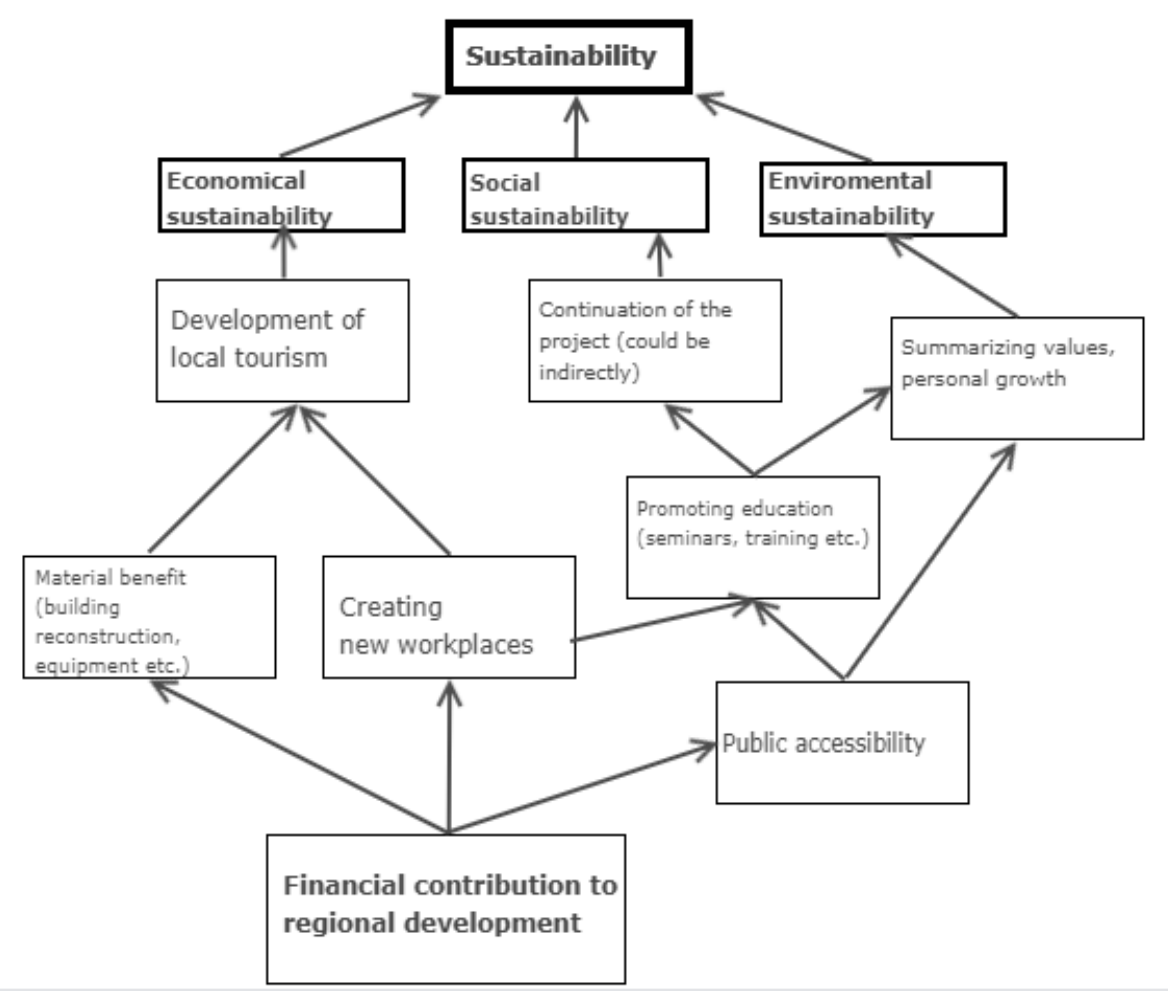

Source: Created by authors using information from research (Grincheva, 2016) and European cultural policy guidelines

Fig. 1. Matrix of evaluation of sustainability of results of cultural projects

The matrix includes a set of quantitative and qualitative data for analytical evaluation, covering both financial and social aspects and indicators allowing to evaluate the contribution of the implemented cultural projects to the overall development strategy, for instance, horizontal priorities - macroeconomic stability, balanced territorial development, sustainable development analysis, as it includes indicators of the use of cultural resources, the financial potential used, social inclusion, etc. The use of well-defined indicators gives a clearer understanding of how to ensure the sustainability of results in the cultural project sector; whereas most of these indicators cannot be measured by specific figures, such as value gains or opportunities for self-learning, both practical analysis of quantitative data and analytical assessment of qualitative data are necessary.

Purpose of the article: to study the practice of ensuring sustainability of results of cultural projects in Zemgale planning region by answering the following research questions: 1) What are the sustainable conditions for the results of cultural projects? 2) What methods are used to ensure the sustainability of cultural projects? What are the key challenges in ensuring the sustainability of cultural projects?

The study is based on two important planners and implementers of cultural policy and projects Zemgale Planning Region and municipalities. Zemgale Planning Region (hereinafter - ZPR) is a derivative public person under the supervision of the Ministry of Environmental Protection and 
Regional Development of the Republic of Latvia (hereinafter - MEPRD), which ensures Zemgale region development planning, coordination, cooperation between municipalities and state administrations. (Zemgales Planosanas regiona nolikums..., 2019; Zemgales planosanas regiona publiskais..., 2019; Zemgales Planošanas regiona attīstības..., 2015). The institution implements and monitors the Zemgale Culture Program (hereinafter - ZCP), an initiative developed and implemented by ZPR since 2011, financed by the State Joint Stock Company "Latvijas valsts mezi" and the State Culture Capital Fund (hereinafter - SCCF) and State Culture Capital Foundation... (Latvijas valsts mezu..., 2019), which is an important financial instrument for implementing cultural projects in Zemgale planning region. The aim of the cultural program is to promote the preservation, popularization, development and accessibility to the general public of the cultural values characteristic to the Zemgale region by contributing to the balanced and qualitative development of the Latvian cultural environment.

The study uses a qualitative and quantitative research approach: a content analysis of cultural projects implemented in Zemgale Planning Region (2011-2018) and documentation of the Zemgale Culture Program implemented by ZPR. The second content analysis collected data on the municipalities in which the ZCP projects were carried out, summarizing the number and distribution of recipient municipalities from the available information. 18 semi-structured interviews were conducted - 12 with cultural project managers from the ZCP and 6 with cultural experts. The study was carried out in 2019.

\section{Research results and discussion}

The summary analysis of the general data shows that 87 different projects related to the cultural sector were implemented in the Zemgale Planning Region during the period under review, of which the most active were 2011 with 17 implemented projects and 2013 with 15 implemented cultural projects.

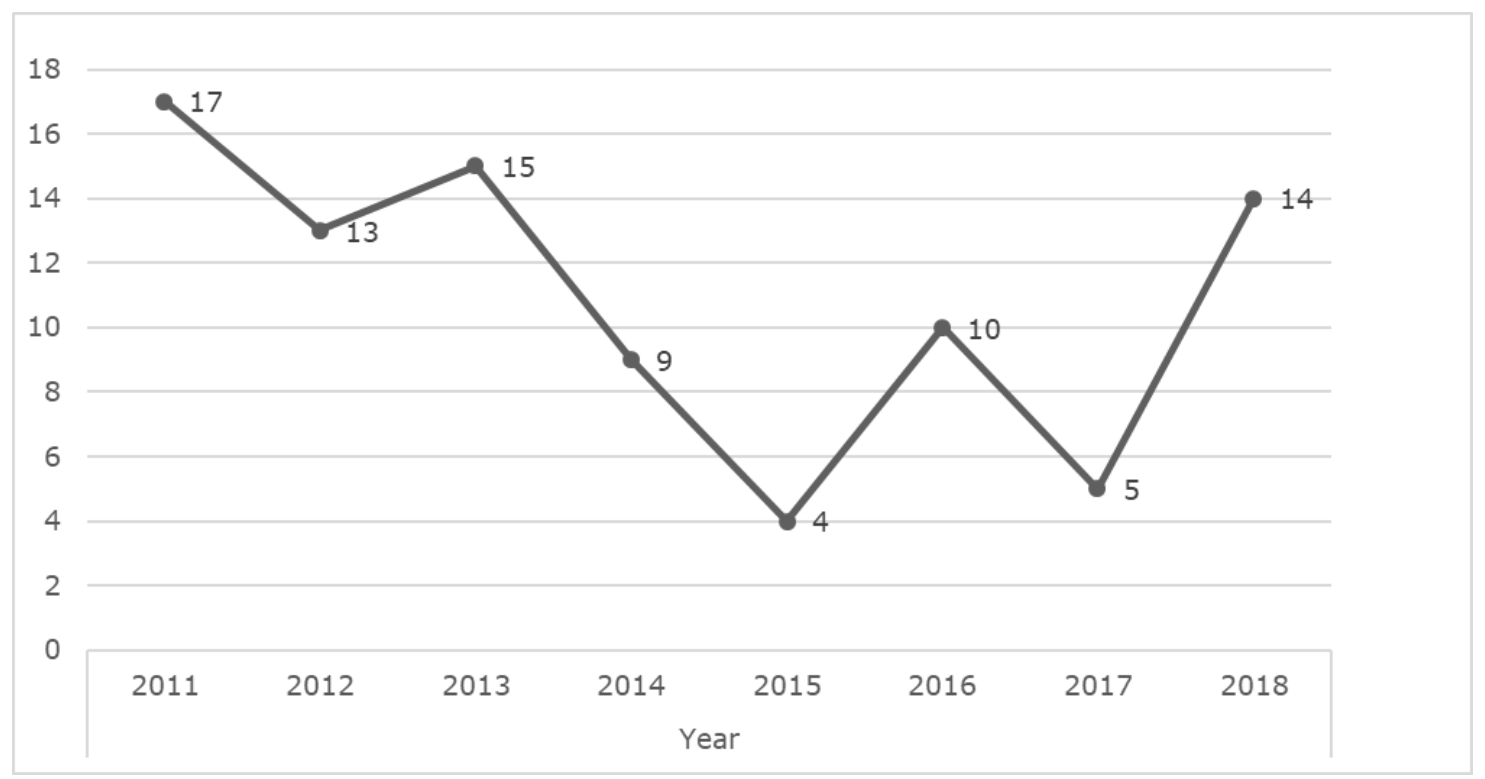

Source: Created by the authors based on content analysis materials

Fig. 2. Dynamics of implemented municipal cultural projects (2011-2018)

The data collected reveal an ambiguous picture of the cultural projects implemented. It has to be taken into account that municipalities implement more financially intensive projects, using EU funds, and co-financing is often necessary, which is often a difficult condition for small municipalities due to limited budget. Funding provided by large funds such as the ERDF, the EAFRD and such allows largescale projects to be implemented over several years; consequently, depending on the human 
resources capacity of the municipality, it is possible to carry out several projects at the same time or to participate in project competitions every year.

According to the collected data, the leader of project implementation is the Jelgava Municipality with 38 projects implemented in the field of culture in 2011-2018, which significantly exceeds other municipalities in the Zemgale Planning Region. This has been the position of the municipality and one of the driving forces is the cultural sector; active participation, allocation of resources and priorities within the budget are good for cultural projects. This is the prerequisite for sustainable project management at municipal level.

As the content analysis shows, there is a significant potential for sustainability when cooperating with related institutions (libraries, cultural centres etc.) within municipalities, and it is one of the preconditions for sustainability as project results are channelled to meet different local needs; one example is the reconstruction and extension of the Zorgi Library premises by the Iecava Municipality, thus creating an active public centre.

The most important challenges that have emerged in the issue of sustainability of the results of cultural projects implemented by municipalities are meeting individual needs based on the supply of EU funds. Although this tendency is not widespread, as most Zemgale municipalities strive to create a "basket of ideas and needs", the existence of this indicator is important if we consider the contribution to sustainability that is not only meeting current needs but investing in all opportunities that will be realized.

The study was continued with the analysis of ZPR documents, which gathered information on cultural projects implemented under the program, which is the second most important opportunity within the region under review. Project promoters mostly represent the same municipalities, which could be explained by successful communication, interest and clear goals. Continuity is not a clear concept in the projects implementing the competition - the vast majority are independent promoters, most often providing some form of entertainment or recreation. From the collected data, it was concluded that a number of projects initially implemented as a one-off event became a tradition due to demand, such as the Liepaja Symphony Orchestra Music Festival in the Rundale Palace Garden, which attracts both museum and local tourism. Another positive example is the early music festival "Sanssouci" in Jekabpils region, which, like Rundale, has become a sign of recognition in a small village far from regional centres. These are positive examples of succession where the implemented cultural projects create new traditions which are particularly important for the development of rural areas. However, most of the projects do not continue and with such a wide representation of promoters within the program do not form a common strategic direction, but rather serve as opportunities for cultural activities.

According to the data, the lowest number of project applicants and implementers is natural persons - $6 \%$ during the reporting period. The project is a team effort; it requires management and implementation that requires human resources. Individuals are most often unable to realize project intentions because the workload and management format - public benefit objectives and results make it more difficult for individuals to accomplish. This is one of the reasons why the number and activity of unions is growing - it is easier to implement ideas and deliver results that are conducive to the growth of society by uniting in communities of interest and gaining a legal basis, and the specificity of culture requires teamwork. A significant influencing factor is that the statute provides that natural persons may only qualify for financial support for research work by claiming it and receiving it as royalty. The relatively low demand leads to the conclusion that the number of such 
persons is small and that the research work is either carried out through other funding channels or in a relatively small number.

There is a growing interest in society for a wide range of public events that include not only entertainment and cultural education, but also leisure and communication. As the overall financial situation of the population improves, so does the demand for this type of project - as the purchasing power of the population increases, cultural activities are of a more commercial nature, which, on the one hand, is undesirable as it suppresses the focus on mental development; but, on the other hand, brings economic benefits to the venue and the business community around it, which is a positive thing. As the population becomes more active, the cultural supply changes along with it and cultural projects have to address the function of improving the current situation. According to the data collected, the lowest activity was observed in video and film production projects ( $3 \%$ ), book and print publishing activities, which could be partly explained by the VKKF-managed project implementation program, which financially supports this type of activity required under the Culture Program. Also, there is little demand for funding for theatrical performances, although amateur collectives operate in several municipalities in Zemgale.

The sustainability criterion for assessing overall strategic development objectives is fully met, as each project activity contributes to the development of the sector, with particular emphasis on cultural heritage conservation and recreational activities as an important contribution to social sustainability.

The results of the analysis confirm that Zemgale region has the opportunity to more purposefully implement its ideas and move towards the set strategic goals in terms of cultural project management, promoting the development and visibility of the cultural sector, as well as accessibility and quality of services. The decrease in the number of implemented projects indicates a loss of interest, while the number of large-scale cultural projects is increasing. The municipality should have a clear plan of action in each of the authorities it oversees; at the same time, the fragmented network of municipalities and the lack of transparency of implementing organizations complicate the efficiency of cultural policy implementation in the region. There is a lack of results analysis both in the field of cultural projects and transparency of economic data, as there is a lack of the mutual communication system that would be needed for the development of cultural projects and cultural sector in Zemgale.

Summarizing the lessons learned from the practical experience of the interviewed project managers, there are a number of key conditions to ensure the sustainability of results:

- When planning project objectives, they must comply with local and / or regional (depending on the scope of the project) regional medium and long term strategies and guidelines;

- All parties involved in decision-making should be involved in planning the implementation of the project idea, collecting opinions and needs;

- Planned results should complement the achievements of previous projects;

- Project results are not only monitored in the form of reports, but are included or, as far as possible, included in the course of other activities;

- Organize an exchange of information and knowledge between the best practices sharing experience and lessons learned on how to deliver the project results after the goal has been achieved;

- Sustainability of the results can be achieved if the project has a partnership that continues the ideas that have been started, in the event that the promoter itself ceases. 


\section{Conclusions, proposals, recommendations}

1) Theoretically, sustainability of results is often perceived as an objective, but it should be the foundation of cultural project management - a set of activities and measures that incorporate the principles of sustainability and achieve a result that ensures these activities continue to the next level.

2) Municipalities should have an obvious plan of action in each of the bodies they oversee; at the same time, the fragmented network of municipalities and the lack of transparency of implementing organizations complicate the effectiveness of cultural policy implementation in the region. There is a lack of results analysis both in the field of cultural projects and transparency of economic data due to the lack of a mutual communication system that would be necessary for the development of cultural projects and cultural sector in Zemgale.

3) Zemgale Planning Region is widely represented in terms of implemented cultural projects by municipalities, associations, institutions, etc. in the sector, as evidenced by the demand for cultural project programs, the funding acquired and the results achieved, but the concreteness for sustainability has more to do with implementer's theory and formal reporting.

4) The feasibility of any cultural project implemented is based on the fulfilment of development plans, but not always this approach is capable of objectively evaluating the implementation of potentially good ideas, which in the long run would make a more valuable contribution to regional development.

5) There is a lack of clearly defined criteria and schemes for assessing the sustainability of the results of cultural projects, which would lead to the collection, analysis and regular evaluation of indicators at regional level, helping to find transparent utility and justification in the use of funding.

6) Defining qualitative and quantitative criteria for the sustainability of results would facilitate a quality cultural project management process as well as project decision-making for future project activities.

7) The most effective methods for ensuring the sustainability of results, according to practical examples from cultural project implementers in Zemgale Planning Region, are planning various activities instead of the implemented project; implementation of related and complementary future projects; planned and regular attraction of investments for the continuation of the project results; regular publicity; regular monitoring to determine visitor satisfaction / needs / ratings.

8) The most important indicators of the contribution of sustainable cultural projects to regional development are the emergence of new traditions, the renewal of cultural heritage, the promotion of local community activity, the creation of new museums, libraries, cultural centres, crafts houses, a noticeable increase in local tourism development, new jobs created and/or existing jobs preserved and so on - all carried out as part of a coherent development strategy.

This work was supported by the National Research Program Project grant number VPP-IZM-2018/1-0015. 


\section{Bibliography}

1. A New European Agenda for Culture. European Commission (2018). Retrieved: https://eurlex.europa.eu/legal-content/EN/TXT/PDF/?uri=CELEX:52018DC0267\&from=EN. Access: 11.09.2019.

2. Asare, I., Hermane, A., Lake, A., Tjarve, B. (2013) Demokratiskas kulturpolitikas veidosana: kultura ka ilgtspejigas attīstības faktors. Vidzemes kulturas un makslas biedriba "Haritas", R., 30 Ipp.

3. Bervar, M., Bertoncelj, A. (2016). The Five Pillars of Sustainability: Economic, Social, Environmental, Cultural and Security Aspects. Retrieved: http://www.hippocampus.si/ISBN/978-961-6984-26-3/151.pdf. Access: 11.12.2019.

4. Clune, W.H., Zender, A.J.B. (2018). The Three Pillars of Sustainability Framework: Approaches for Laws and Governance (Vol. 9, 18 March 2018), Journal of Environmental Protection, pp. 211-240

5. Council conclusions on participatory governance of cultural heritage (2014/C 463/01). Official Journal of the European Union (Vol. 54, 23 December 2014), EU, Brussels, 32 p.

6. Environmental, Cultural, Social and Economic sustainability [s.a.]. Retrieved: http://www.morethangreen.es/en/ideology/four-sustainabilities-cultural-economic-social-environmentalsustainability/\#sthash.J580pbWg.qtdSAPJ1.dpbs. Access: 20.12. 2019.

7. Grincheva, N. (2016). Sustainable Development in Cultural Projects: Mistakes and Challenges. Development in Practice, 26, pp. 236-250.

8. Guy, G.B., Kibert, J.C. (1998). Developing Indicators of Sustainability: US experience, Building Research \& Information, 26:1, pp. 39-45.

9. Latvijas valsts mežu un Valsts Kultūrkapitāla fonda atbalstītās "Zemgales kultūras programmas 2019" nolikums. Retrieved: https://www.zemgale.lv/nozares/kultura/zemgales-kulturas-programma. Access: 15.12.2019.

10.Scammon, D. (2012). Sustainability and Culture: How do they work together? Retrieved: http://www.academia.edu/1817961/Sustainability_and_Culture_How_do_they_work_to._ Access: 25.11.2019.

11. Silvius, G., Schipper, R., Planko, J., Van der Brink, J., Kohler, A. (2017). Sustainability in Project Management. Routledge, ProQuest Ebook Central, 42 p.

12. Silvius, A.J.G., Schipper, R.P.J. (2014). Sustainability in Project Management: a Literature Review and Impact Analysis. Social Business, Vol. 4, No. 1, pp.63-96. Retrieved: https://pmworldlibrary.net/wpcontent/uploads/2018/06/2014-Silvius-Schipper-Sustainability-in-project-management.pdf. Access: 22.10.2019.

13. Soini, K., Dessein, J. (2016). Culture-Sustainability Relation: Towards a Conceptual Framework. Retrieved: https://www.mdpi.com/2071-1050/8/2/167/html. Access: 18.12. 2019.

14. Tufinio, P.S., Mooi, H., Ravestijn, W., Bakker, H., Boorsma, M. (2013). Sustainability in project management: where are we? International Journal of Engineering, Tome XI (Year 2013), Fascicule 1 (ISSN 1584-2665), pp. 91-100.

15.Zemgales Planošanas regiona attistibas programma 2015 - 2020, (2015), 1. redakcija. Apstiprinata ar 18.08.2015. ZPRP lemumu Nr. 131 (protokols Nr.27).

16. Zemgales Planošanas regiona nolikums (2017). (Izdots saskana ar Regionālās attistibas likuma 161.panta 2. dalu). Retrieved: https://www.zemgale.Iv/par-zpr/nolikums. Access: 10.01.2020.

17.Zemgales planošanas regiona publiskais parskats 2018, (2019). Apstiprinats 2019.g.18. junija ar ZPRAP lēmumu Nr. 111. Retrieved: https://www.zemgale.Iv/par-zpr/publiskie-parskati. Access: 15.01.2020. 